\title{
Vallasta ja konteksteista
}

Kommentoin tässä muutamaa Pia Livia Hekanahon ”Poliittisen käsitteestä ja kirjallisuudentutkimuksen monimuotoisuudesta” -kirjoituksessa esiintyvää väitettä.

Hekanahon väite 1: Malmio argumentoi "ad hominem".

Ainoat ad hominem eli henkilöön kohdistuva argumentit, joita käytän, tulevat nyt: Hekanahon väite, jonka mukaan minä argumentoin ad hominem, on argumentointia ad hominem.

Lisäksi Hekanahon kirjoitus ”Teorian vastaisku: pitääkö humanistin äänestää republikaaneja?" Avaimen numerossa 1/2007 täyttää ad hominem-argumentoinnin tuntomerkit. Hänelle Theory's Empire -kirjassa olennaista on se, että teos on tietynlaisten henkilöiden, "tunnettujen yliopistokonservatiivien", toimittama (Hekanaho 2007, 76). Minun mielestäni kulloinkin arvioitavana oleva teos on arvioitava sen sisällön perusteella.

Hekanahon väite 2: Poliittisuus ja siihen liittyvät argumentit ja tulkinnat.

Väite 2a. Malmio ja Avaimen toimittajat Haapala ja Rossi ymmärtävät Hekanahon kirjoituksessa esiintyvän poliittisuus-käsitteen värin, liian kapeasti.

Väite 2b: Laajempi poliittisuus-käsite on hyödyllinen tutkimuksessa.

Siihen, miten Hekanaho tässä numerossa olevassa vastineessaan argumentoi tutkimuksen laajemman poliittisuuden puolesta, ei minulla ole huomauttamista. Foucault ja Althusser taitavat tässä vaiheessa olla jo kaikille tuttuja, eikä Hekanaho tuo keskusteluun tältä osin mitään uutta. Hän perustelee kantansa usein esitetyillä väitteillä ja ajatuksilla. Voin hyvin hyväksyä nämä argumentit, mutta samalla ne herättävät minussa seuraavanlaisia kysymyksiä: Onko valta oikeasti joka paikassa, aina ja kaikkialla ja määrittää kaikkea toimintaamme? Onko valta ainoa tai ensisijainen ihmisen toimintaa ohjaava motiivi? Onko olemassa muita toiminnan motiiveja? Millä perusteella valtaa pidetään ihmisen toiminnan perimmäisenä motiivina? Riippuvatko toiminnan motiivit kontekstista? Minkä perusteella voimme tietää, että nimenomaan tämä konteksti - valta - on "pysyvä" tai ensisijainen, "taattu"? Minkälaisessa kontekstissa tällainen näkemys syntyy, kasvaa, saa valtaa? Minkälainen ihmiskäsitys löytyy tämän ajatuksen taustalta? Millä perusteella valta on valittu tutkimuksen "pysyväksi” kontekstiksi?

Ehkä minä ja Avaimen toimittajat Haapala ja Rossi ymmärsimme Hekanahon käyttämän poliittisuus-käsitteen "väärin” siksi, että Hekanahon Theory’s Empire -teokseen, sen toimittajiin ja kirjan kontekstiin kohdistama kritiikki (Hekanaho 2007, 76-79) osittain oli poliittista sanan kapeassa merkityksessä?

Väite 2 c: "Malmio [--] tulkitsee ainoastaan amerikkalaiskampuksilla esiintyvän tar- 
peita turvata akateemisen toimintaympäristön moniarvoisuus, oikeudenmukaisuus ja tasa-arvoisuus".

Esitän, että konteksti on erilainen. Tasa-arvoisuus, oikeudenmukaisuus ja keskinäisiä eroja kunnioittava toimintaympäristö - kyllä, ilman muuta, niin USA:ssa kuin Suomessa. Mutta: Suomen historia, politiikka, maantieteellinen sijainti, väestöpohja ja niin edelleen on toisenlainen kuin USA:n. Näin kattavien erilaisuuksien voi olettaa synnyttävän kovin toisennäköisiä lukijoita ja vallan verkostoja: esimerkiksi erilaisia suhtautumisia kirjallisuustieteellisiin antologioihin.

\section{Kristina Malmio}

\section{Lähteet}

HEKANAHO, PIA LIVIA: Teorian vastaisku: pitääkö humanistin äänestää republikaaneja? Kirjallisuudentutkimuksen aikakausilehti Avain 1/2007, 76-79.

Theory's Empire. An Anthology of Dissent. Toim. Daphne Patai ja Will H. Corral. Columbia University Press 2005.

Keskustelu kirjallisundentutkimuksen poliittisuudesta päättyy tällä erää tähän. Kiitämme keskustelijoita virkistävistä puheenvuoroista!

Avaimen toimitus 